\title{
ホウレンソウ自動収穫装置における土の移動を考慮した根切り刃の経路設計
}

\author{
藤澤 彰宏 $^{* 1}$, 千田 有一 ${ }^{* 2}$
}

\section{Path planning of the root-cutting blade for the automatic spinach harvester in consideration of movement of soil}

\author{
Akihiro FUJISAWA ${ }^{* 1}$ and Yuichi CHIDA ${ }^{* 2}$ \\ ${ }^{* 1}$ Interdisciplinary Graduate School of Science and Technology, Shinshu University \\ 4-17-1 Wakasato, Nagano 380-8553, Japan \\ ${ }^{*} 2$ Faculty of Engineering, Shinshu University \\ 4-17-1 Wakasato, Nagano 380-8553, Japan
}

Received: 5 October 2016; Revised: 29 March 2017; Accepted: 14 May 2017

\begin{abstract}
This paper describes about path planning for a root-cutting blade of an automatic spinach harvester. Automatic harvesters for spinach have not been widely used among farmers because mechanical harvesting easily spells bruises to stems and leaves. We have been developing the harvester which successfully harvests spinach without bruising stems and leaves. The path which blade moves in soil is very important in order to attain desired performance and to reduce the amount of soil which is pushed by the blade is the most meaningful factor for successful execution. In this paper, first, we discuss about a method to reduce the amount of soil and proposed a constraint equation for the method. Next, an appropriate path of the blade of the harvester is proposed by using the equation. The effectiveness of the proposed path is verified by numerical simulations based on the Discrete Element Method (DEM).
\end{abstract}

Key words : Agriculture robot, Automatic harvester, Discrete Element Method (DEM), Path planning

\section{1. 緒論}

生食用ホウレンソウは主として手作業で収穫されており，その場合の収穫・調製作業時間は全作業時間の $84 \%$ を占めるため（長野県農業経営指標，2014）機械による自動化が望まれている. そのため，さまざまなホウレン ソウ収穫機が開発されており（小林，1998）（吉田他，2000）（西澤，2012）（平野他，2013）（千田，2015）（ひ らかさねっと，2015），とくに平野他（2013），千田（2015）による収穫装置は把持や挟み込みを伴わない収穫方 法であるために，ホウレンソウの葉や茥を傷つけずに収穫できる特徵をもつ。その収穫装置では根切り刃を土中 に侵入させ，クローラーによって前進しながらその推力によって根切り刃でホウレンソウの根を押し切り，根切 り刃後方の適切な位置に配置したベルトコンベアによって回収する収穫方法を用いている．しかしながら，この 収穫方法では土中に侵入している根切り刃によって押しのけられた土が前方のホウレンソウに覆いかぶさり，収 穫に悪影響を及ぼす場合がある。そのため，土中進行させる根切り刃経路が非常に重要となる，そこで，藤澤他 （2015）は土中を移動する根切り刃が土に与える影響に着目して解析し，回収の成功率を向上させるには土中を推 移する根切り刃が押しのける土の量を低減することが重要であることを定量的に示すとともに, 適切な根切り刃 経路を指摘した。このような，根切り刃を例とする剛体と土との相互作用を考慮した経路設計についてはいくつ

\footnotetext{
No.16-00472 [DOI:10.1299/transjsme.16-00472], J-STAGE Advance Publication date: 25 May, 2017

*1 正員, 信州大学大学院 総合工学系研究科（†380-8553 長野県長野市若里 4-17-1）

*2 正員, 信州大学 工学部

E-mail of corresponding author: 14st205k@shinshu-u.ac.jp
} 


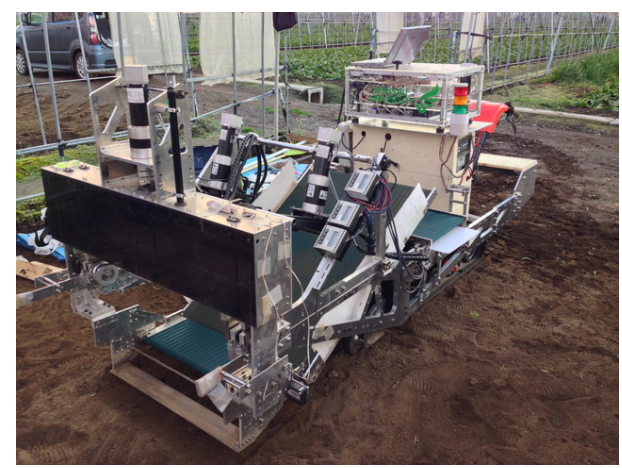

Fig. 1 Developed automatic spinach harvester.

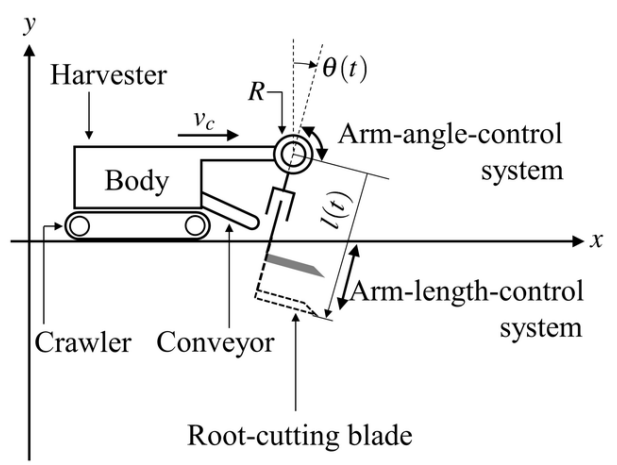

Fig. 2 Overview of the harvester.

かの先行研究が存在する．たとえば Jaroslaw 他（2008）はショベルカーにおけるバケットの経路最適化について 議論している．また，吉田他（2012a）（2012b）は個別要素法を用いたショベルカーのバケットの経路に対する反 力の検証とバケットの経路生成を, Lui 他（2014）は月面上の細かい砂礫であるレゴリスのロボットアームとバ ケットによるサンプリングについてバケット経路を生成し，個別要素法を用いて解析している．ほかにも，酒井 （1992）は耕うん時の土中深くの土を破砕する振動式サブソイラの経路によるけん引抵抗の違いをシミュレーショ ンと実験により検証しており，皿田他（2000）はホイールローダーのバケットによる土砂のすくい取り作業を効率 化するために反力を考慮したバケットの経路生成を, 張他（2001）はホイールローダーの知能化のためにファジ イ推論を用いてバケットのすくい取り動作の経路生成をしている.しかしながら，これらの先行研究は深層の土を 表層へかきあげるような土の大変位を対象とした経路設計や検証であるために，ホウレンソウの根切り時に発生 する微小な土の移動を対象とした経路設計は議論されていない。一方で, 山口他（2016）は，藤澤他（2015）の 知見に基づき, 根切り刃の姿勢を考慮した根切り刃運動をさせることで，土中を推移する根切り刃によって押し のけられる土の量の低減化を図っている，具体的には，根切り刃の向きを常に自身が移動する方向へ向け続ける ように根切り刃運動を拘束することで，根切り刃により押しのけられる土の量を低隇化した根切り刃経路を提案 している. しかしながら, 山口他（2016）における機構動作の拘束は幾何学的考察に基づいて十分条件を導出し ているものの，機構動作の拘束の必要十分条件は明確になっていない，そこで本論文では，土の微小挙動に着目 した考察に基づき，根切り刃の土中進行に伴って押しのけられる土の量を低減する根切り刃経路を設計する．根 切り刃が押しのける土の量を低減化することは，ホウレンソウ自動収穫において有利となる（藤澤他，2015）。具 体的には，山口他（2016）と同様に根切り刃の移動方向と根切り刃の姿勢に着目し，千田（2015）の根切り刃経 路を改良する観点に立って新たな根切り刃経路を提案する。その際, 代数的考察から機構動作の拘束に対する必 要十分条件を導出する。. また, 提案した根切り刃経路が, 藤澤他（2015）における土の微小挙動の観点から収穫 に有利な経路となっていることを個別要素法によって検証する.

\section{2. 問 題 設 定}

\section{$2 \cdot 1$ 対象とする収穫装置}

本論文では千田（2015)によって開発されたホウレンソウ収穫装置を対象として議論する. 図 1 に開発された収 穫装置を, 図 2 に収穫装置の模式図を示す。対象とする収穫装置は, クローラー, アーム角度制御機構, アーム 長制御機構, 根切り刃, ベルトコンベアによって構成される. クローラ上部に本体を設置し, 前方部にアーム角 度制御機構，アーム長制御機構が取り付けられている。アームには根切り刃が直角に固定されており，アームを 軸 $R$ を中心に回転させることで根切り刃の角度を変えることができる. よって, 根切り刃の角度はアームの回転 角 $\theta(t)$ と同一と考えることができる. 一方, アーム長 $l(t)$ を変えることで根切り刃の鉛直方向位置を可変とする 構造となっている．根切り刃後方にベルトコンベアが設置されており，根切り後のホウレンソウを回収できる構 成としている，本論文では根切り刃の動作に着目するので，コンベアの動作については省略する，収穫では，ク ローラーを一定速度 $v_{c}$ で進行させることで, 根切り刃を一定速度で進行させる. 根切り刃の動作を考えるために $x-y$ 座標系を考え, クローラーの進行方向を $x$ の正方向, 鉛直上向きを $y$ とする. なお, クローラーが進行する 地面は水平であるものとして考える. また，地表面位置は $y=0[\mathrm{~m}]$ である. 


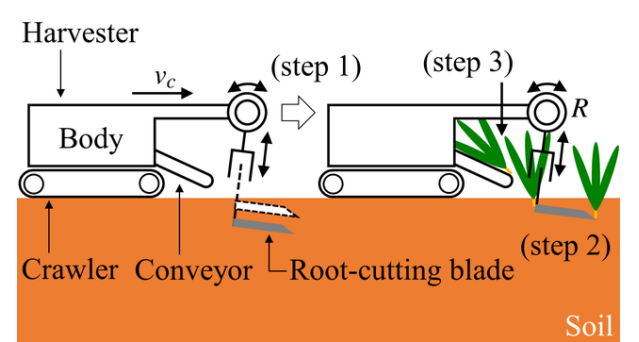

Fig. 3 Procedure of automatic harvesting. First, the crawler moves forward by constant speed (step 1). Next, roots of spinach are cut in soil by the root-cutting blade in front of the harvester (step 2 ). Root-cut spinach are carried by the conveyor (step 3).

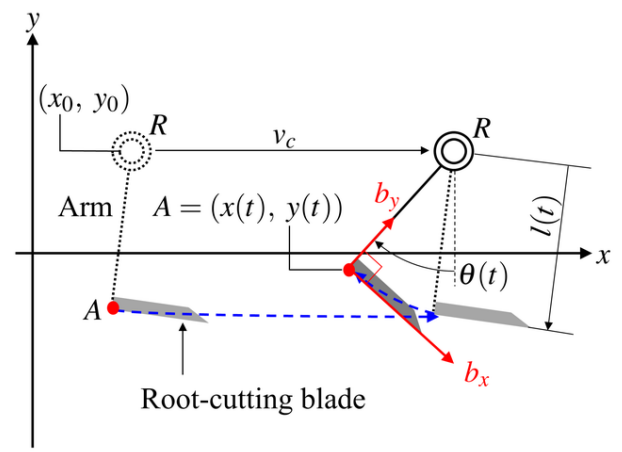

Fig. 4 Parameters and axis for generating harvesting motion.

Table 1 Parameters for harvester motion.

\begin{tabular}{c|l|rl}
\hline$(x, y)$ & Position of the root-cutting blade & {$[\mathrm{mm}]$} \\
$\left(x_{0}, y_{0}\right)$ & Initial position of rotational center, $R$, of the arm & $(0,485)$ & {$[\mathrm{mm}]$} \\
$\theta_{0}$ & Center angle of the conventional path & 5 & {$[\mathrm{deg}]$} \\
$\alpha$ & Amplitude of $\theta(t)$ & 5 & {$[\mathrm{deg}]$} \\
$f$ & Frequency of $\theta(t)$ & 0.35 & {$[\mathrm{~Hz}]$} \\
$L_{c}$ & Arm length in the conventional path & 508 & {$[\mathrm{~mm}]$} \\
$v_{c}$ & Velocity of the crawler & 60 & {$[\mathrm{~mm} / \mathrm{s}]$} \\
\hline
\end{tabular}

図 3 に収穫手順の模式図を示す. 収穫では, クローラーを一定速度 $v_{c}$ で進行させることで, 根切り刃を一定速 度で進行させる（step 1)。よって，根切りはクローラーの推進力を用いて押し切りされる. その際，根切り刃の 角度を地表面下向きとすると, $-y$ 方向の力が根切り刃に作用するため, 土中に侵入させることができる（畠山他， 2015）. 根切り刃を土中で進行させることでホウレンソウの根を切る (step 2) . その後, 後段のベルトコンベア で根切り後のホウレンソウを回収搬送する（step 3）。ホウレンソウは約 $5[\mathrm{~mm}]$ 以上の根を残す必要があるため, 根切り刃は一定深さを保つ必要がある. そのため, 地表面位置を変位センサで検知し, アーム長制御機構によって アーム長 $l(t)$ を追従制御させることで, 地表面の凹凸や土中の障害物の影響を抑制している（畠山他，2016）. ま た，自動収穫を実現するためには根切り刃の経路が非常に重要である. 自動収穫に効果的な根切り刃経路は，アー 厶角度制御機構によってアームの角度 $\theta(t)$ を正弦波運動させると同時に, クローラーを一定速度で進行させるこ とで実現している（藤澤他，2015）。このように，対象とする収穫装置ではクローラーの速度 $v_{c}$, 根切り刃の位 置 $l(t)$ と角度 $\theta(t)$ の 3 つの自由度で動作させているが, 本論文ではクローラー速度は一定とし, 根切り刃の位置 と角度の 2 自由度を活用して，より適切な経路生成について考える。

\section{$2 \cdot 2$ 従来の根切り刃経路}

千田（2015），藤澤他（2015）によれば，図 1 に示す収穫装置において，良好な自動収穫を実現できる根切り刃 経路が提案されている. 本論文では，千田（2015），藤澤他（2015）で示された根切り刃経路を基本経路として考 え，基本経路に修正を加えることでより良い経路を生成する．まず，図 4 に根切り刃の動作を考えるための模式 図と変数の定義を示す. 図において, アームの回転中心 $R$ は, 一定速度 $v_{c}$ で進行するクローラーに伴って初期位 置 $\left(x_{0}, y_{0}\right)$ から $x$ 軸正方向に平行移動する. 同時に, 軸 $R$ を中心としたアームの回転 $\theta(t)$ およびアーム長 $l(t)$ の 変化量によって根切り刃経路が定まる. 根切り刃の経路を考えるため, 根切り刃の根元の位置を点 $A=(x(t), y(t))$ としておく.ここで， $t$ は時間を表す．アームの角度 $\theta(t)$ は鉛直軸から時計回りの回転角にとる. 実際の自動収 穫装置では圑場の凹凸に対応してアーム長 $l(t)$ を制御しているが，本論文は根切り刃経路について議論するため, アーム長制御の影響は除外して考えるものとする．また， $b_{x} ， b_{y}$ は，それぞれ根切り刃底面に沿った方向の単位 ベクトル，根切り刃に直交した方向の単位ベクトルであり，根切り刃の進行方向を議論する際に用いる.このと 


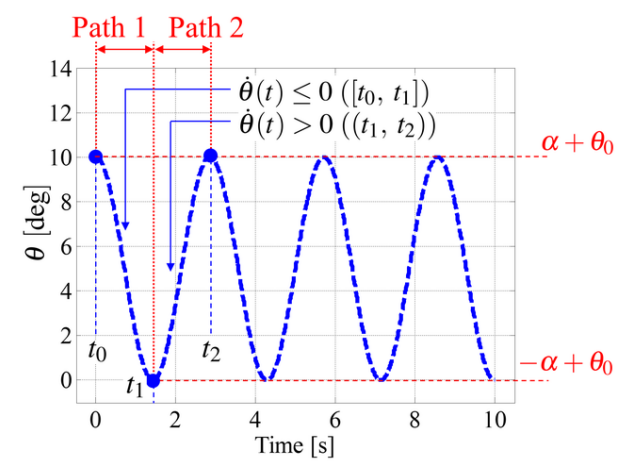

Fig. $5 \theta(t)$ by Eq.(3). $\quad \dot{\theta}(t) \leq 0$ and $\dot{\theta}(t)>0$ correspond to Path 1 and Path 2, respectively.

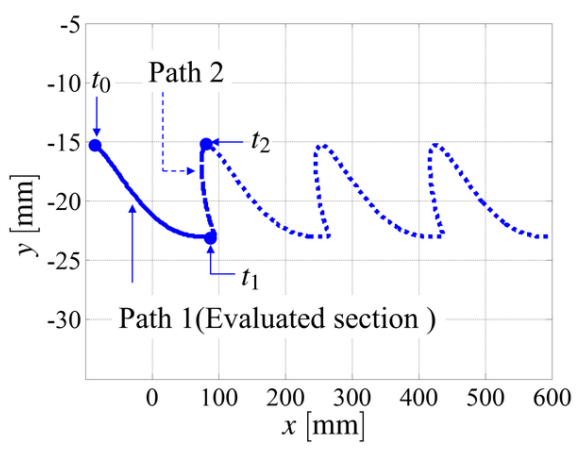

Fig. 6 Trajectory of point $A$ of the blade by the conventional path. Path 1 and Path 2 are repeated.

き, 点 $A$ の座標はアームの角度 $\theta(t)$, 長さ $l(t)$, クローラー速度 $v_{c}$ を用いて次のように表される.

$$
\begin{aligned}
& x(t)=x_{0}-l(t) \sin \theta(t)+v_{c} \cdot t \\
& y(t)=y_{0}-l(t) \cos \theta(t)
\end{aligned}
$$

千田（2015）, 藤澤他（2015）で示されている根切り刃経路は, クローラーを一定速度 $v_{c}$ で進行させ, 同時にアー 厶角度 $\theta(t)$ を次式で運動させることで実現している.

$$
\begin{aligned}
\theta(t) & =\alpha \cos 2 \pi f t+\theta_{0} \\
l(t) & =L_{c} \text { (Const.) }
\end{aligned}
$$

ただし， $\theta_{0}$ は $\theta(t)$ の振幅の中心角度， $\alpha$ は振幅， $f$ は周波数である. また, アーム長 $l(t)$ は期待する根切り刃深 さに基づいて定めた一定值 $L_{c}$ としている.これらのパラメータを表 1 にまとめる. 式（3），(4）によって生成さ れる根切り刃経路を従来経路とよぶ，さらに，以降で述べる提案経路では， $\theta(t)$ については式 (3) と同じ動作を させつつ, $l(t)$ の自由度を活用してより有利な経路生成を試みる.

式（3）と表 1 のパラメータによって定まる $\theta(t)$ を図 5 に示す. $t_{0}=0, t_{1}:=1 /(2 f), t_{2}:=1 / f$ とし, $t \in\left[t_{0}, t_{1}\right]$ における経路を経路 $1 ， t \in\left(t_{1}, t_{2}\right)$ を経路 2 とする．すなわち，アームを前方に振る $\dot{\theta}(t) \leq 0$ のときに経路 1 とな り, 逆に $\dot{\theta}(t)>0$ のときに経路 2 となる. さらに, 式（1）-（4）に基づいて根切り刃 $A$ 点の座標を求めると, 図 6 となり, 経路 1 と経路 2 を繰り返す周期的な経路となる. 図 6 より, 経路 1 では, 根切り刃を下降させながら前 進させている．この期間において， ホウレンソウの根を押し切ることができるが，根切り刃の土中移動に伴って 土を前方に送り出してしまう. 一方, 経路 2 では, 根切り刃を上昇させて次の周期の初期位置に復帰させる動作 となっている．この期間では，根切り刃は前方に移動せず，鉛直上方に移動するのみであるため，土を前方に移動 させない. 経路 1 と経路 2 の 2 つの経路を 1 周期とした経路を繰り返すことにより, 根切り刃経路は構成されて いる.

\section{$2 \cdot 3$ 考える問題}

藤澤他（2015）によれば, 根切り刃が土中を移動する際に, 根切り刃によって土を押しのけ, 前方に移動させ る量を低減することが，提案方法による自動収穫においては有利であることが明らかとなっている．また，本論 文で述べた従来経路は成功裏に自動収穫を実現できる経路として確認済みであり，この経路と大きく異なる経路 による自動収穫は実現できていない。そのため，本論文では，従来経路を基本経路と考え，さらに従来経路にお いて一定值としていたアーム長 $l(t)$ を活用することで, 根切り刃運動に伴って移動する土の量を低減することを 考える. 図 6 で示される通り, 従来経路では経路 1 と経路 2 を繰り返していた. 経路 1 では, 図 7 に示すように, 根切り刃は前方に進行して根を切る. その際, 根切り刃の移動によって土を前方に押し出してしまうため, その 量を低減することが望ましい，一方，経路 2 では図 8 のように，根切り刃は鉛直方向に移動するが前方には移動 しないために，土の移動を伴ったとしてもホウレンソウの自動収穫に悪影響を及ぼさないことが圃場実験結果に よって確認されている，そこで，本論文では根切り刃の運動に伴って前方に移動させる土の量を低減する点に注 目するため, 経路 2 については考慮しないものとし, 経路 1 に限定して考えることにする. 次に, 経路 1 におい 


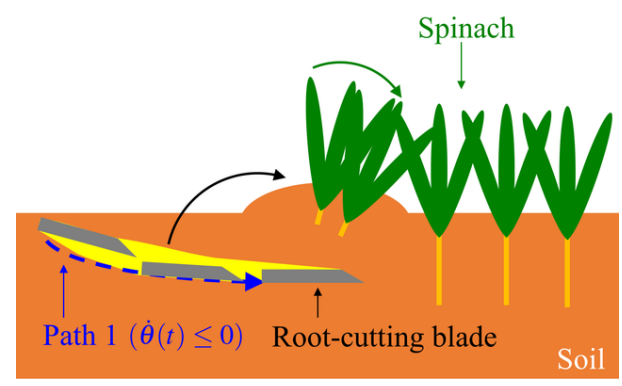

Fig. 7 Movement of the blade in the Path 1. The blade moves to forward direction.

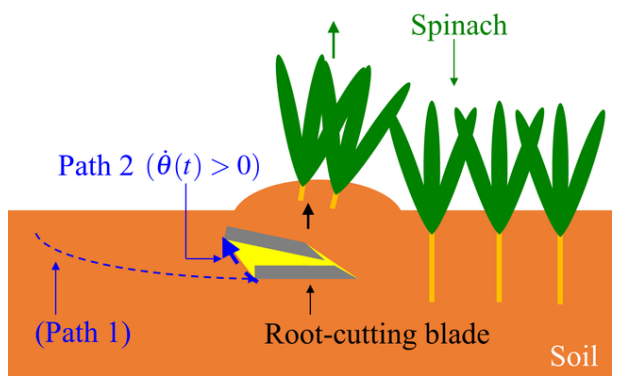

Fig. 8 Movement of the blade in the Path 2. The blade moves to vertical direction.

て, 根切り刃の変位に伴って前方に移動する土の量を低減することを考える. そのためには, 根切り刃が通過する 体積を低減することが効果的である，いま，図４において，根切り刃が通過する面積を考える．このとき，根切 り刃の進行方向である $b_{x}$ 方向に移動する場合には, 移動に伴って根切り刃の厚さ分だけの面積を通過する. 一方, アームの進行方向ではない $b_{y}$ 方向への移動量が増えると, 根切り刃の厚さだけでなく, 幅の影響も加わることに なり通過面積が増える可能性がある.すなわち，移動距離が一定であるとした場合には，根切り刃の進行方向で ある $b_{x}$ 方向への移動が最も通過面積を小さくする，そこで， $\theta(t)$ を従来と同様にしたとき， $l(t)$ を活用すること で根切り刃底面の進行方向を $b_{x}$ 方向に拘束することを考え，それによって根切り刃の通過体積を低減する。この とき, 根切り刃を水平状態に保ったまま平行移動させると良いように考えられるが，実際には根切り刃の角度を 水平よりも下向きにして進行させなけ机ば根切り刃が $y$ 軸正方向に上昇してしまう. そのため, 本論文では根切り 刃が水平な状態から $x$ 軸正方向に直線的に進行する経路については対象外とする.

\section{3. 根切り刃進行方向に拘束運動させるための条件の導出}

\section{$3 \cdot 1$ 土の移動量を低減するための根切り刃運動の拘束条件}

根切り刃の運動に伴って移動する土の量を低減するため, 根切り刃の運動方向を図 4 の $b_{x}(t)$ 方向に拘束する経 路生成について考える. その際，変位 $\theta(t)$ については式（3）によって与えられているとし，アーム長 $l(t)$ の満た すべき条件を導出する．本来は，根切り刃底面の進行方向について考えるべきであるが，本論文では，図 4 に示 すように, 根切り刃の根元の点 $A$ の運動に簡単化して考える. すなわち, 根切り刃はアームに対して直角に固定 されているため, 点 $A$ の速度を $v_{a}(t)$ としたとき, $v_{a}(t)$ が $b_{y}(t)$ 方向と直交しているときに根切り刃の進行方向は $b_{x}(t)$ 方向に拘束されるとして条件を導く.このとき, $v_{a}(t) \perp b_{y}(t)$ が，根切り刃が $b_{x}(t)$ 方向へのみ移動するため の必要十分条件となる．そこで, $v_{a}(t) \perp b_{y}(t)$ より $l(t)$ が満たすべき条件を導出する. まず, 根切り刃の根元の点 $A$ における速度ベクトル $v_{a}(t)$ は，式（1），(2) を時間 $t$ で微分すると

$$
\begin{aligned}
v_{a}(t) & =(\dot{x}(t), \dot{y}(t))^{\mathrm{T}} \\
\dot{x}(t) & =-\dot{l}(t) \sin \theta(t)-l(t) \dot{\theta}(t) \cos \theta(t)+v_{c} \\
\dot{y}(t) & =-\dot{l}(t) \cos \theta(t)+l(t) \dot{\theta}(t) \sin \theta(t)
\end{aligned}
$$

となる，一方， $b_{y}(t)$ は，図 4 に示すべクトルの関係から

$$
b_{y}(t)=(\sin \theta(t), \cos \theta(t))^{\mathrm{T}}
$$

と表せる. いま， $v_{a}$ と $b_{y}(t)$ が直交しているとき，2つのベクトルの内積は 0 なので

$$
v_{a}(t)^{\mathrm{T}} b_{y}(t)=0
$$

が成り立つ.式（9）に式（5）と式（8）を代入すると

$$
\dot{x}(t) \sin \theta(t)+\dot{y}(t) \cos \theta(t)=0
$$




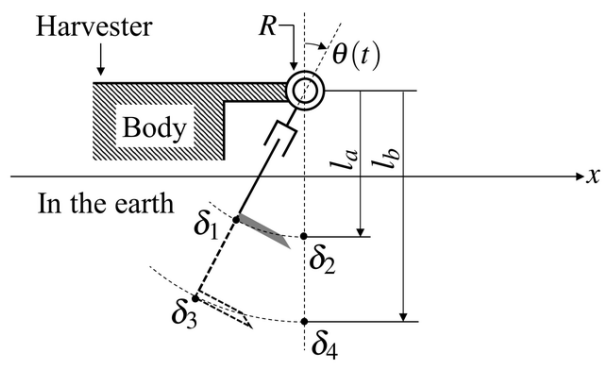

Fig. 9 Difference of the path by $l_{0}$. The path $\delta_{1}-\delta_{2}$ by $l_{0}=l_{a}$ is shorter than that path $\delta_{3}-\delta_{4}$ by $l_{0}=l_{b}$ because of $l_{a}<l_{b}$.

となるので，式（10）の $\dot{x}(t) ， \dot{y}(t)$ に式（6），(7）をそれぞれ代入して整理すると

$$
\begin{aligned}
& v_{c} \sin \theta(t)-\dot{l}(t) \sin ^{2} \theta(t)-\dot{l}(t) \cos ^{2} \theta(t)-l(t) \dot{\theta}(t) \sin \theta(t) \cos \theta(t)+l(t) \dot{\theta}(t) \sin \theta(t) \cos \theta(t)=0 \\
\Leftrightarrow & v_{c} \sin \theta(t)-\dot{l}(t)\left(\sin ^{2} \theta(t)+\cos ^{2} \theta(t)\right)=0 \\
\Leftrightarrow & \dot{l}(t)=v_{c} \sin \theta(t)
\end{aligned}
$$

を得る. 式 $(11)$ は $v_{a}(t) \perp b_{y}(t)$ となるための必要十分条件である. よって, 式 $(11)$ を満たすように $l(t)$ を変位 させれば，根切り刃を自身の向いている方向（ $b_{x}$ 方向）に進行させることができる. 対象とする経路は経路 1 で あることを考慮すると，式（11）を満たす $l(t)$ は，式 $(11)$ を時間 $\left[t_{0}, t\right]$ の範囲で定積分することにより得られ る.すなわち

$$
\int_{t_{0}}^{t} i(\tau) \mathrm{d} \tau=l(t)-l\left(t_{0}\right)
$$

より

$$
l(t)=\int_{t_{0}}^{t} i(\tau) \mathrm{d} \tau+l\left(t_{0}\right)=v_{c} \int_{t_{0}}^{t} \sin \theta(\tau) \mathrm{d} \tau+l\left(t_{0}\right)
$$

となる. $l\left(t_{0}\right)=: l_{0}$ とおくと, 式 $(13)$ は

$$
l(t)=v_{c} \int_{t_{0}}^{t} \sin \theta(\tau) \mathrm{d} \tau+l_{0}
$$

と表せる. よって, 与えられた $\theta(t)$ に応じて, アーム長 $l(t)$ を式（14）によって調整することで式（11）を満た すことができる，そのため, 式 (11) は経路 1 における $l(t)$ の目標軌道となる.

\section{$3 \cdot 2$ アーム長の初期条件 $l_{0}$ についての考察}

式 (14) の第 1 項は $\theta(t)$ によって定まるが, 第 2 項の $l_{0}$ は設計パラメータとして残る. $l_{0}$ は経路 1 におけるアー ム長の初期長さを表しており, ホウレンソウの根切り位置と根切り刃の通過体積のトレードオフを考慮して定め る. たとえば, 図 9 に示すように, アーム長を $l_{0}=l_{a}$, あるいは $l_{0}=l_{b}$ に固定して動作させた場合では, $\theta(t)$ によ るアームの回転によって根切り刃が通過する経路長は異なる. すなわち, $l_{0}=l_{a}$ のときの経路長 $\delta_{1}-\delta_{2}$ は $l_{0}=l_{b}$ の時の経路長 $\delta_{3}-\delta_{4}$ より短いため, 根切り刃の通過体積の観点においては $l_{0}=l_{a}$ のほうが有利となる. 一方, 木 ウレンソウを根を適切な長さで切断するためには, 根切り刃を土中の所望の深さで進行させる必要があるため, $l_{0}$ が短か過ぎると所望の根の長さを残せない. 以上より, 初期アーム長 $l_{0}$ には, 目標とするホウレンソウの根の切 断位置によって定まる $l_{0}$ の下限值と, 根切り刃の変位に伴って移動する土の量の上限值によって定まる $l_{0}$ の上限 值がある. $l_{0}$ の下限值については, 次節で議論する. また, $l_{0}$ の上限值については, 従来経路による土の移動量 との比較によって 5.4 節において議論する.

\section{3 $l_{0}$ の下限值}

$l_{0}$ の下限值については, 期待される根切り後のホウレンソウの根の長さから決まる. ホウレンソウの商品価值 を保つためには, 切断後の根を $5[\mathrm{~mm}]$ 以上残すことが求められる. 一方, それ以上の長さで根を切断することに 
Path 1 Path 2

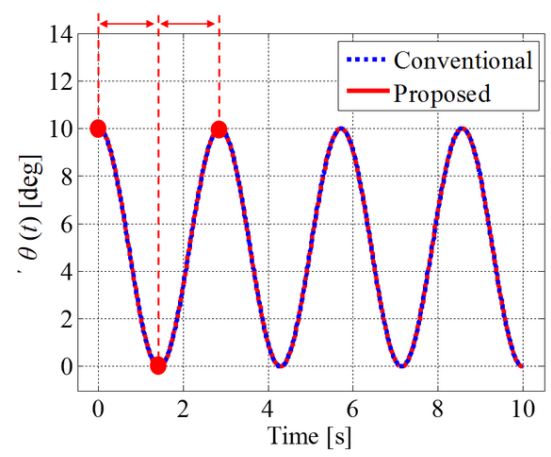

Fig. $10 \theta(t)$ of the proposed path. $\theta(t)$ of the two paths Fig. 11 are the same.

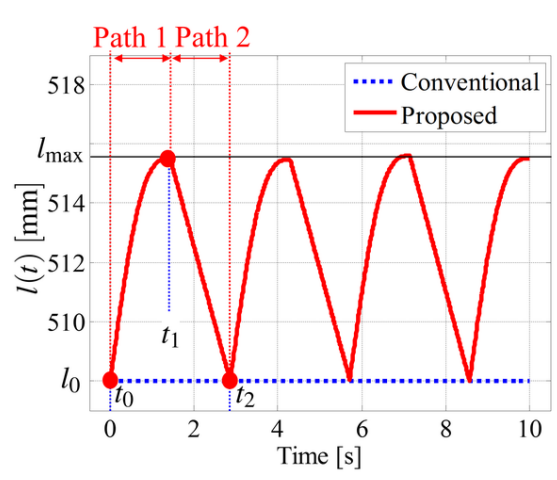

$l(t)$ of the proposed path. $l(t)$ is constant in the conventional path, but $l(t)$ is modified by Eq.(17) in the proposed path.

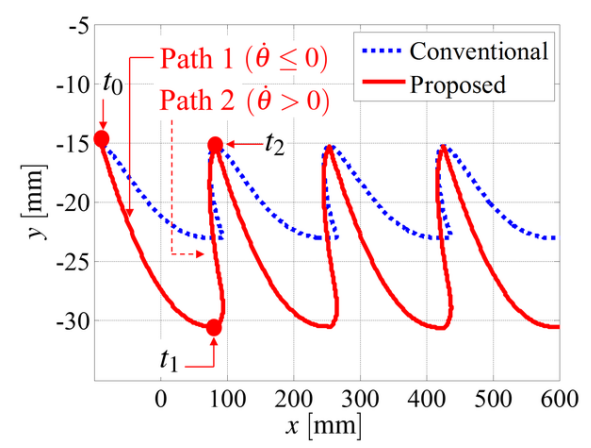

Fig. 12 Proposed path.

ついて問題にならない，そこで，地表面の凹凸や植え込み深さ等の影響を考え，根切り長さに余裕を加えた目標 值を用いることとした，具体的には，図 6 に示されるように，従来経路では， $L_{c}=508[\mathrm{~mm}]$ とすることで，最も 浅い深さにおいても地表面下 15 [mm] となるようにアーム長を設定しているため, 提案経路においても同じ深さ となるよう $l_{0}$ を設定することとした。 ゆえに， $l_{0} \geq 508[\mathrm{~mm}]$ と設定した。

\section{4. 通過体積を低減化した根切り刃経路の提案}

従来経路の式 (3) に加え, $l(t)$ を式 (14) によって駆動させることで根切り刃の動きを $b_{x}$ 方向に拘束すること ができ，通過体積を低減化した根切り刃経路にできる。そこで，この考え方によって新たな根切り刃経路を提案 する．まず，経路 1 について考える. 経路 1 では，根切り刃の通過体積を低減化および適切な根切り位置とする ために $l_{0}$ を設定し, 式 (14) によって得られる $l(t)$ にってアーム長を調節する. $l_{0}$ につては, 根切り刃経路 の最上点が従来経路と同じ值となるように $l_{0}=508[\mathrm{~mm}]$ とした． $l_{0}$ の妥当性については次章で議論する.このと き, $l(t)$ の目標軌道は

$$
l(t)=v_{c} \int_{0}^{t} \sin \theta(\tau) \mathrm{d} \tau+l_{0}
$$

となる. 次に, 経路 2 について考える. 経路 2 については, 本論文で対象とする根切り刃の通過体積の低減化と は無関係であり，経路 1 と経路 2 の繰り返しによって経路全体が実現できればよい.このためには，経路 1 にお いて伸長したアーム長を $l_{0}$ まで復帰させる目標入力を印加すればよい. そこで, アーム長を線形的に経路 1 の初 期状態に復帰させる入力を加えることとする. 以上より式（3）を加えた次式を提案経路とする. ただし，経路 1 


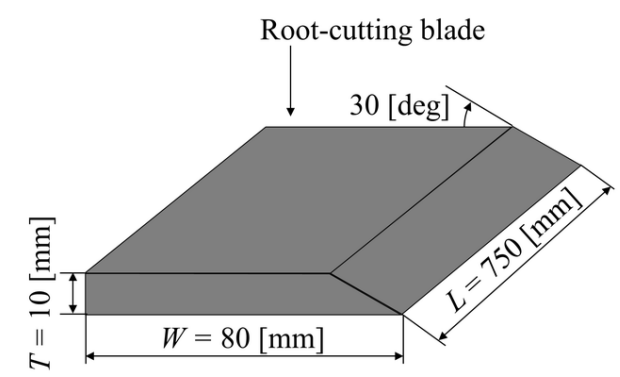

Fig. 13 Dimension of the root-cutting blade.

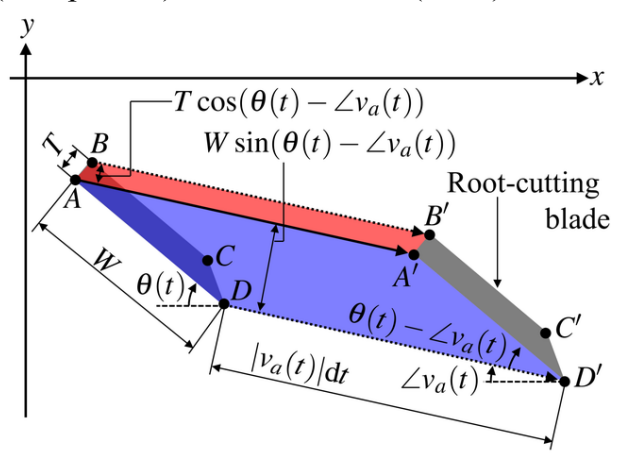

Fig. 14 Definition of $\mathrm{d} V\left(=\mathrm{d} V_{1}+\mathrm{d} V_{2}\right)$. The blade $A B C D$ moves to $A^{\prime} B^{\prime} C^{\prime} D^{\prime}$ in parallel within infinitesimal time.

の初期時刻は便宜上 $t_{0}=0$ と考え，経路の各周期において時間 $t$ を 1 周期ずらして取り扱うものとする.

$$
\begin{aligned}
\theta(t) & =\alpha \cos 2 \pi f t+\theta_{0} \\
l(t) & =\int_{0}^{t} \dot{l}(\tau) \mathrm{d} \tau+l_{0} \\
i(\tau) & = \begin{cases}v_{c} \sin \theta(\tau) & (\dot{\theta}(\tau) \leq 0) \\
-2 f\left(l_{\max }-l_{0}\right) & (\dot{\theta}(\tau)>0)\end{cases} \\
l_{\max } & :=v_{c} \int_{0}^{t_{1}} \sin \theta(\tau) \mathrm{d} \tau+l_{0}
\end{aligned}
$$

ここで $l_{\max }$ は $l(t)$ の最大值を表す. 図 10 に時間ごとの $\theta(t)$, 図 11 に数值積分した時間ごとの $l(t)$, 図 12 に提案 経路を示す. 提案経路では, 図 10 のように $\theta(t)$ は従来経路のままである一方, 図 11 のように経路 1 においてアー 厶長 $l(t)$ を伸長させ, 経路 2 において線形的にアーム長 $l(t)$ を $l_{0}$ まで縮めている. これによって, 図 12 のような 経路 1 と経路 2 の繰り返しとなる根切り刃経路が実現されている.

\section{5. 土の移動量に着目した $l_{0}$ の上限值の導出と根切り刃通過体積の比較}

\section{$5 \cdot 1$ 根切り刃の通過体積の計算方法}

根切り刃の運動に伴って移動する土の量は, 根切り刃の通過体積に相当するため, その体積量によって評価す る. 本稿では図 6 における経路 1 を議論の対象とするため, 経路 1 における通過体積を計算する. ただし, 根切 り刃は図 13 に示すものであり, その寸法は刃厚 $T=10[\mathrm{~mm}]$, 刃幅 $W=80[\mathrm{~mm}]$, 刃渡り $L=750[\mathrm{~mm}]$ である. 根切り刃の通過体積は, 微小時間 $\mathrm{d} t$ の間に根切り刃が移動することに伴って発生する通過体積 $\mathrm{d} V(t)$ を積分する ことによって求める. 図 14 に根切り刃が微小時間 $\mathrm{d} t$ の間に移動するときに生じる通過体積 $\mathrm{d} V(t)$ の模式図 $(x-y$ 平面断面図）を示す. 微小時間 $\mathrm{d} t$ において, 根切り刃 $A B C D$ は点 $A^{\prime} B^{\prime} C^{\prime} D^{\prime}$ に平行移動すると仮定する. このと き, 微小時間 $\mathrm{d} t$ における根切り刃の通過体積 $\mathrm{d} V(t)$ は図 14 における点 $A, A^{\prime}, B^{\prime}, B$ で囲まれた赤い台形の領域 と, 点 $A, D, D^{\prime}, A^{\prime}$ で囲まれた青い台形の領域によって構成される. 赤い領域 $A, A^{\prime}, B^{\prime}, B$ の体積を $\mathrm{d} V_{1}$, 青い領 域 $A, D, D^{\prime}, A^{\prime}$ の体積を $\mathrm{d} V_{2}$ とすると, それぞれ

$$
\begin{aligned}
& \mathrm{d} V_{1}(t)=T \cos \left(\theta(t)-\angle v_{a}(t)\right) L\left|v_{a}(t)\right| \mathrm{d} t \\
& \mathrm{~d} V_{2}(t)=W \sin \left(\theta(t)-\angle v_{a}(t)\right) L\left|v_{a}(t)\right| \mathrm{d} t
\end{aligned}
$$

となる.ただし， $v_{a}(t)$ は根切り刃の速度であり

$$
\begin{aligned}
& \left|v_{a}(t)\right|:=\sqrt{\dot{x}(t)^{2}+\dot{y}(t)^{2}} \\
& \angle v_{a}(t):=-\tan ^{-1} \frac{\dot{y}(t)}{\dot{x}(t)}
\end{aligned}
$$

である．よって, 微小時間 $\mathrm{d} t$ における根切り刃の通過体積 $\mathrm{d} V(t)$ は, 式（18），(19）の和なので

$$
\mathrm{d} V(t)=\mathrm{d} V_{1}(t)+\mathrm{d} V_{2}(t)=\left\{T \cos \left(\theta(t)-\angle v_{a}(t)\right)+W \sin \left(\theta(t)-\angle v_{a}(t)\right)\right\} L\left|v_{a}(t)\right| \mathrm{d} t
$$


Table 2 Parameters for calculation of soil volume the blade pushed.

\begin{tabular}{c|l|r}
\hline $\mathrm{d} V$ & Infinitesimal volume the blade pushed & {$\left[\mathrm{mm}^{3} / \mathrm{s}\right]$} \\
$\mathrm{d} V_{1}$ & Infinitesimal volume the blade pushed by the blade of $T$ & {$\left[\mathrm{~mm}^{3} / \mathrm{s}\right]$} \\
$\mathrm{d} V_{2}$ & Infinitesimal volume the blade pushed by the blade of $W$ & {$\left[\mathrm{~mm}^{3} / \mathrm{s}\right]$} \\
$v_{a}(t)$ & Velocity of the blade $\left(:=(\dot{x}(t), \dot{y}(t))^{\mathrm{T}}\right)$ & {$[\mathrm{mm} / \mathrm{s}]$} \\
$\left|v_{a}(t)\right|$ & Magnitude of $v_{a}(t)\left(:=\sqrt{\dot{x}(t)^{2}+\dot{y}(t)^{2}}\right)$ & {$[\mathrm{mm} / \mathrm{s}]$} \\
$\angle v_{a}(t)$ & Angle of $v_{a}(t)$ from the $x$ coordinate $\left(:=-\tan ^{-1} \frac{\dot{y}(t)}{\dot{x}(t)}\right)$ & {$[\mathrm{deg}]$} \\
$V$ & Total amount of volume the blade pushed by the blade with the Path 1 & {$\left[\mathrm{~mm}^{3}\right]$} \\
\hline
\end{tabular}

であり，根切り刃の通過体積 $V$ は，経路 1 の積分区間が $\left[t_{0}, t_{1}\right]$ であることを考慮すると

$$
V=\int_{t_{0}}^{t_{1}} \mathrm{~d} V=\int_{t_{0}}^{t_{1}}\left\{T \cos \left(\theta(t)-\angle v_{a}(t)\right)+W \sin \left(\theta(t)-\angle v_{a}(t)\right)\right\} L\left|v_{a}(t)\right| \mathrm{d} t
$$

となる. 表 2 に，根切り刃の速度と通過体積の定義をまとめておく.

\section{$5 \cdot 2$ 従来経路における根切り刃の通過体積}

式（22）を解析的に計算することは容易ではないため，時間刻み幅 $0.001[\mathrm{~s}]$ としてオイラー法を用いた数值積 分により近似計算する。式（3），(4）に示す従来経路における経路 1 の通過体積を $V_{c}$ と表したとき，式（22）を 数值積分することによって $V_{c}=2335 L\left[\mathrm{~mm}^{3}\right]$ と求まる. 提案経路による通過体積は, 従来経路による $V_{c}$ よりさ い值となることが必要である.

\section{$5 \cdot 3$ 提案経路における根切り刃の通過体積}

提案経路による根切り刃の通過体積を見積る. このとき, $l_{0}$ を大きくすると, 根切り刃の通過経路が増え, 通 過体積が増える. よって, 経路 1 における通過体積を $V_{c}$ より小さくする $l_{0}$ の上限值を確認する必要がある. その ため，はじめに提案経路の経路 1 における通過体積を $V_{p}$ と表し， $V_{p}$ を求める. まず， $\theta(t)$ の目標入力である式 （3）と, $l(t)$ の目標入力である式（14）によって生成される根切り刃経路にあるとき, 根切り刃速度 $v_{a}(t)$ を $v_{p}(t)$ と表す。このとき，式（22）より $V_{p}$ は

$$
V_{p}=\int_{t_{0}}^{t_{1}}\left\{T \cos \left(\theta(t)-\angle v_{a}(t)\right)+W \sin \left(\theta(t)-\angle v_{a}(t)\right)\right\} L\left|v_{p}(t)\right| \mathrm{d} t
$$

となる. 式 (23) において, $\theta(t)$ は根切り刃の角度であり, $\angle v_{p}(t)$ は根切り刃とその進行方向ベクトルのなす角で ある. 式（14）に従ってアーム長が駆動されているとき, $v_{p}(t)$ と $b_{y}(t)$ は直交しているので $\angle v_{a}(t)=\theta(t)$ となる ため, $\theta(t)-\angle v_{p}(t)=0$ を式（23）に代入して整理すると

$$
\begin{aligned}
V_{p} & =\int_{t_{0}}^{t_{1}}(T \cos 0+W \sin 0) L\left|v_{p}(t)\right| \mathrm{d} t \\
& =T L \int_{t_{0}}^{t_{1}}\left|v_{p}(t)\right| \mathrm{d} t
\end{aligned}
$$

を得る. 式（24）は，根切り刃の通過体積 $V_{p}$ が根切り刃速度 $\left|v_{p}(t)\right|$ に依存しており, 速度が大きいほど $V_{p}$ が大 きくなることを意味している。 これは, 図 9 に示すように, アーム長が長いほど根切り刃の回転半径が大きくな り周速度も増えるが，その場合には通過する経路長も長くなるために通過体積が増えることに対応している.

\section{$5.4 l_{0}$ の上限値の見積り}

式（24）における $\left|v_{p}(t)\right|$ の上限值を見積る. まず, 根切り刃速度が $v_{p}(t)$ のとき, 式（11）が成り立っているの で，式（11）を式（6），式（7）に代入して整理すると

$$
\begin{aligned}
\dot{x}(t) & =-v_{c} \sin ^{2} \theta(t)-l(t) \dot{\theta}(t) \cos \theta(t)+v_{c} \\
& =v_{c} \cos ^{2} \theta(t)-l(t) \dot{\theta}(t) \cos \theta(t) \\
& =\cos \theta(t)\left(v_{c} \cos \theta(t)-l(t) \dot{\theta}(t)\right)
\end{aligned}
$$




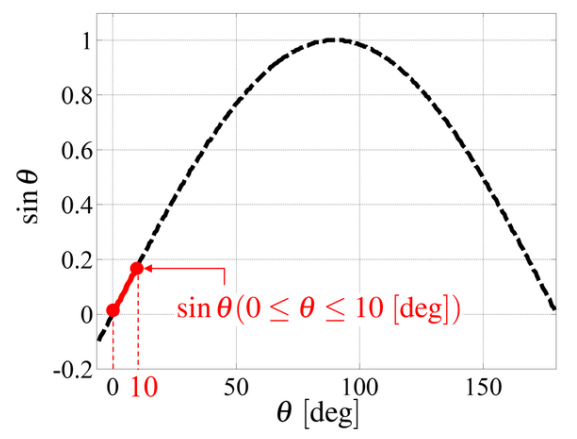

Fig. 15 Range of $\sin \theta(t)$.

$$
\begin{aligned}
\dot{y}(t) & =-v_{c} \sin \theta(t) \cos \theta(t)+l(t) \dot{\theta}(t) \sin \theta(t) \\
& =\sin \theta(t)\left(-v_{c} \cos \theta(t)+l(t) \dot{\theta}(t)\right)
\end{aligned}
$$

となる．上式の平方 $\dot{x}(t)^{2}, \dot{y}(t)^{2}$ を式（20）へ代入して整理すると

$$
\begin{aligned}
\left|v_{p}(t)\right| & =\sqrt{\left(\cos ^{2} \theta(t)+\sin ^{2} \theta(t)\right)\left(v_{c} \cos \theta(t)-l(t) \dot{\theta}(t)\right)^{2}} \\
& =\left|v_{c} \cos \theta(t)-l(t) \dot{\theta}(t)\right|
\end{aligned}
$$

を得る. 式（27）の $l(t)$ へ式（14）を代入して整理すると

$$
\begin{aligned}
\left|v_{p}(t)\right| & =\left|v_{c} \cos \theta(t)-\left(v_{c} \int_{t_{0}}^{t} \sin \theta(\tau) \mathrm{d} \tau+l_{0}\right) \dot{\theta}(t)\right| \\
& =\left|v_{c} \cos \theta(t)-v_{c} \dot{\theta}(t) \int_{t_{0}}^{t} \sin \theta(\tau) \mathrm{d} \tau+l_{0} \dot{\theta}(t)\right| \\
& \leq\left|v_{c} \cos \theta(t)\right|+\left|v_{c} \dot{\theta}(t) \int_{t_{0}}^{t} \sin \theta(\tau) \mathrm{d} \tau\right|+\left|l_{0} \dot{\theta}(t)\right|
\end{aligned}
$$

となる. 式（29）の右辺各項の上界を求める. まず, 右辺第 1 項について $\cos \theta(t) \leq 1$ なので

$$
\left|v_{c} \cos \theta(t)\right| \leq\left|v_{c}\right|=v_{c}
$$

を得る. 次に, 式（29）の右辺第 2 項について考える. まず, 式（3）を時間 $t$ で微分することで

$$
\dot{\theta}(t)=-2 \pi f \alpha \sin 2 \pi f t \leq 2 \pi f \alpha
$$

を得る. $\int_{0}^{t} \sin \theta(\tau) \mathrm{d} \tau$ については, 式（3）より $\theta(t)$ の変域は $-\alpha+\theta_{0} \leq \theta(t) \leq \alpha+\theta_{0}$ であり, 表 1 より $\alpha=5[\mathrm{deg}], \theta_{0}=5[\mathrm{deg}]$ であることを考慮すると, $0 \leq \theta(t) \leq 10[\mathrm{deg}]$ となる.このとき, $\sin \theta(t)$ は図 15 と なり, $\theta(t)=\alpha+\theta_{0}=10[\mathrm{deg}]$ のとき $\sin \theta(t)$ は最大となることから次式を得る.

$$
\left|\int_{t_{0}}^{t} \sin \theta(\tau) \mathrm{d} \tau\right| \leq\left|\int_{t_{0}}^{t} \sin \left(\alpha+\theta_{0}\right) \mathrm{d} \tau\right|=\left|\sin \left(\alpha+\theta_{0}\right) \cdot\left(t-t_{0}\right)\right|
$$

である. 経路 1 における時間を考えているので, $t \leq t_{1}$ であることを考慮すると, 式 (31), 式 (32) より, 式 (29) 右辺第 2 項について

$$
\left|v_{c} \dot{\theta}(t) \int_{t_{0}}^{t} \sin \theta(\tau) \mathrm{d} \tau\right| \leq\left|2 \pi f \alpha v_{c} \sin \left(\alpha+\theta_{0}\right) \cdot\left(t-t_{0}\right)\right| \leq 2 \pi f \alpha v_{c} \sin \left(\alpha+\theta_{0}\right) \cdot\left(t_{1}-t_{0}\right)
$$

が成り立つ. 最後に, 式（29）の右辺第 3 項について, 式（31）より

$$
\left|l_{0} \dot{\theta}(t)\right| \leq\left|2 \pi f \alpha l_{0}\right|=2 \pi f \alpha l_{0}
$$

を得る，以上の式（30），(33），(34）より

$$
\left|v_{p}(t)\right| \leq v_{c}+2 \pi f \alpha v_{c} \sin \left(\alpha+\theta_{0}\right) \cdot\left(t_{1}-t_{0}\right)+2 \pi f \alpha l_{0}=: \gamma
$$




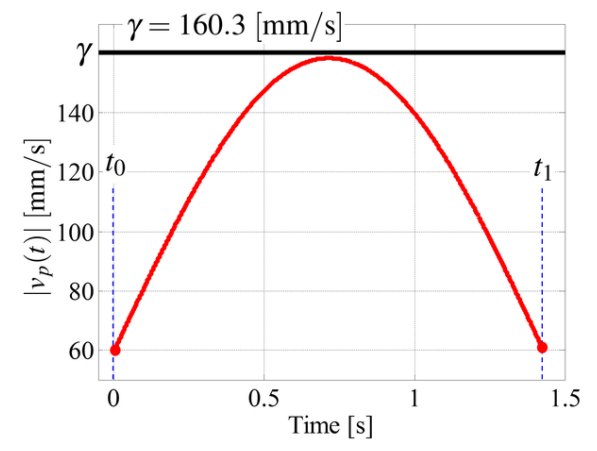

Fig. 16 Velocity of the root-cutting blade in the proposed path.

とすると, 式 $(24)$ より $V_{p} \leq T L \cdot \gamma \cdot\left(t_{1}-t_{0}\right)$ を得る. よって, $T L \cdot \gamma \cdot\left(t_{1}-t_{0}\right)<V_{c}$ であれば $V_{p}<V_{c}$ が保証される. したがって,

$$
v_{c}+2 \pi f \alpha v_{c} \sin \left(\alpha+\theta_{0}\right) \cdot\left(t_{1}-t_{0}\right)+2 \pi f \alpha l_{0}<\frac{V_{c}}{T L\left(t_{1}-t_{0}\right)}
$$

を $l_{0}$ について整理すると

$$
l_{0}<\frac{V_{c}}{2 \pi f \alpha T L\left(t_{1}-t_{0}\right)}-\frac{v_{c}}{2 \pi f \alpha}-v_{c} \sin \left(\alpha+\theta_{0}\right) \cdot\left(t_{1}-t_{0}\right)
$$

を得，表 1 のパラメータに基づいて上式右辺を計算すると

$$
l_{0}<524[\mathrm{~mm}] \Rightarrow V_{p}<V_{c}
$$

を得る．ただし， $\alpha+\theta_{0}=10[\mathrm{deg}], t_{1}-t_{0}=1.43[\mathrm{~s}]$ である．以上より， $l_{0}<524[\mathrm{~mm}]$ とすれば, $V_{p}<V_{c}$ は保証 され，式（3），(14）によって生成された経路の通過体積は従来経路よりも低減化される.

\section{$\mathbf{5 . 5} l_{0}$ の設計条件のまとめ}

3.3 節および 5.4 節より,$l_{0}$ の設計条件は

$$
508 \leq l_{0}<524[\mathrm{~mm}]
$$

である．ホウレンソウを根切りしつつ通過体積を低減するために， $l_{0}$ は式（39）の範囲内より選択される必要が ある。

\section{6 提案経路における通過体積の評価}

4 章で述べた提案経路が条件式（35），(39）を満たしていることを確認し，従来経路との通過体積を比較する．ま ず， $l_{0}$ については式 $(39)$ の条件を満たしているため, $l_{0}=508[\mathrm{~mm}]$ は妥当であることがわかる. また，図 16 に 提案経路における根切り刃の速度と上界 $\gamma$ を示す. 式 (35) を表 1 の值で計算すると， $\gamma=160.3[\mathrm{~mm} / \mathrm{s}]$ となった. ただし， $\alpha+\theta_{0}=10[\mathrm{deg}], t_{1}-t_{0}=1.43[\mathrm{~s}]$ である. 一方，提案経路における根切り刃速度の最大值は $158.4[\mathrm{~mm} / \mathrm{s}]$ であり $\left|v_{p}(t)\right| \leq 158.4[\mathrm{~mm} / \mathrm{s}]$ となる. よって, $\left|v_{p}(t)\right|<\gamma$ であることが確認できる. 次に, 通過体積について比較 する. 提案経路の経路 1 における根切り刃の通過体積を $V_{p}$ とおく. 表 3 に従来経路における経路 1 の通過体積 $V_{c}$ と提案経路における経路 1 の通過体積 $V_{p}$ とその差 $V_{c}-V_{p}$ を示す. 提案経路では, 式（11）と式（38）を満たし た入力を印加しているため, $V_{p}$ は $V_{c}$ に対して $587 L\left[\mathrm{~mm}^{3}\right]$ 改善している.

\section{DEM による検証方法}

\section{1 検証の概要と環境の構築}

提案経路の有用性を検証するために，土と剛体の相互作用の解析に様々な実績のある個別要素法（DEM）（中 嶋，2006）（田中，2006）（吉田他, 2012a，2012b）（Lui et al., 2014）（藤澤他, 2015）による解析をする. 根切り 
Table 3 Comparison of passage volumes between the conventional path and the proposed path.

\begin{tabular}{rl}
\hline & $V\left[\mathrm{~mm}^{3}\right]$ \\
\hline Conventional path, $V_{c}$ & $2335 L$ \\
Proposed path, $V_{p}$ & $1748 L$ \\
\hline Difference, $V_{c}-V_{p}$ & $587 L$ \\
\hline
\end{tabular}

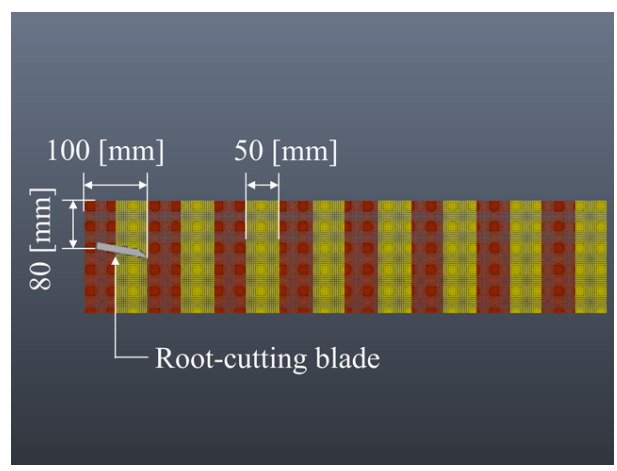

Fig. 17 The side view of the environment by DEM.

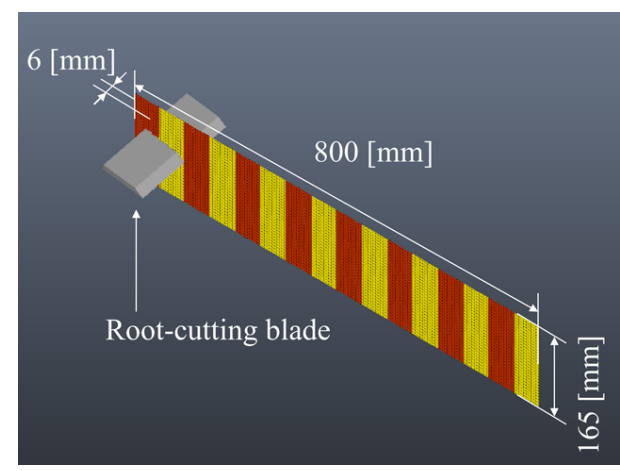

Fig. 18 The sketch of the environment by DEM.

Table 4 Parameters of the particles of soil in simulations by DEM.

\begin{tabular}{c|l|rl}
\hline$\rho_{s}$ & Density of particles & 2550 & {$\left[\mathrm{~kg} / \mathrm{m}^{3}\right]$} \\
$D_{p}$ & Diameter of particles & 3 & {$[\mathrm{~mm}]$} \\
$\mu_{s c}$ & Static friction coefficient between particles and the square container & 0 & {$[-]$} \\
$\mu_{d c}$ & Dynamic friction coefficient between particles and the square container & 0 & {$[-]$} \\
$K$ & Spring constant & 44800 & {$[\mathrm{~N} / \mathrm{m}]$} \\
$E_{r}$ & Coefficient of restitution & 0.0001 & {$[-]$} \\
$\mu_{s p}$ & Static friction coefficient between particles & 0.9 & {$[-]$} \\
$\mu_{d p}$ & Dynamic friction coefficient between particles & 0.85 & {$[-]$} \\
$\mu_{s b}$ & Static friction coefficient between particles and the root-cutting blade & 0.4 & {$[-]$} \\
$\mu_{d b}$ & Dynamic friction coefficient between particles and the root-cutting blade & 0.25 & {$[-]$} \\
\hline
\end{tabular}

刃は図 2 の $x-y$ 平面上を推移するために奥行き方向への土の移動は考慮しなくてよいが, $x-y$ 平面上における土 の挙動については十分に圃場を再現しなければならない.そこで DEMによる土の挙動は, 藤澤他（2015）により 設定された汎用パッケージソフトウェアを用いて平面上におけるホウレンソウ圃場の土の挙動を解析するための 環境を用いて解析する．詳細は藤澤他（2015）の文献にあるため，ここでは概要のみ述べる．検証のための土壌 と根切り刃は, 汎用パッケージソフトウェアである Particleworks ${ }^{\circledR}$ に実装されている 3 次元 DEM 機能を使い構 築している. 図 17 と図 18 に構築された環境を示す.土壌は, 直方体の容積を有する透明な容器の中に平面状の 粒子群を格納することによって再現した。図 18 において, 根切り刃は $x-y$ 平面上を左奥から右手前へと推移す る. また根切り刃の推移に対する土の挙動の視認性を向上させるために，図 17 に示すように粒子は 50 [mm]ごと に帯状の縞模様に分けている. 検証した土の挙動は, この縞模様の変化に注目して評価する. 構築されている環 境における根切り刃の断面は図 13 に示すものであり, $2 \cdot 1$ 節における収穫機の根切り刃と同一である.

\section{$6 \cdot 2$ 個別要素法のためのパラメータ設定}

設定したパラメータは, 粒子の密度 $\rho_{s}$, 粒子の直径 $D_{p}$, 粒子と仮想的に設定した容器の間の静止摩擦係数 $\mu_{s c}$ と動摩擦係数 $\mu_{d c}$, バネ定数 $K$, 反発係数 $E_{r}$, 粒子間の静止摩擦係数 $\mu_{s p}$ と動摩擦係数 $\mu_{d p}$ および粒子と根切り刃 の間の静止摩擦係数 $\mu_{s b}$ と動摩擦係数 $\mu_{d b}$ である. 本論文では, 先行研究である表 4 に示す藤澤他（2015）によっ てホウレンソウ固場を対象として設定されたパラメータを利用する。これらのパラメータは，ホウレンソウ固場 を対象として設定されたパラメータであるため，本検証で用いることは妥当である. 


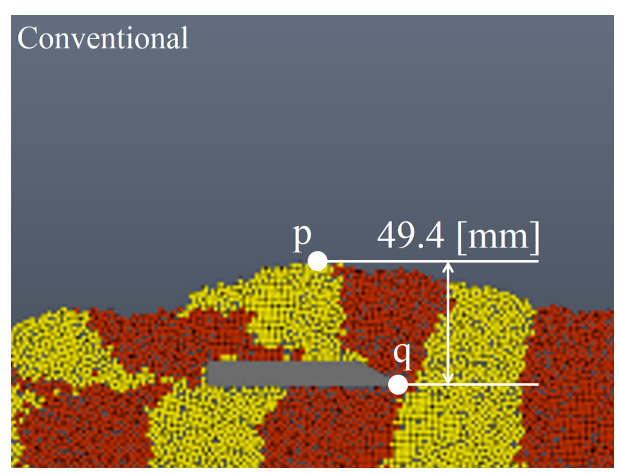

Fig. 19 A result of the simulation by the conventional path.

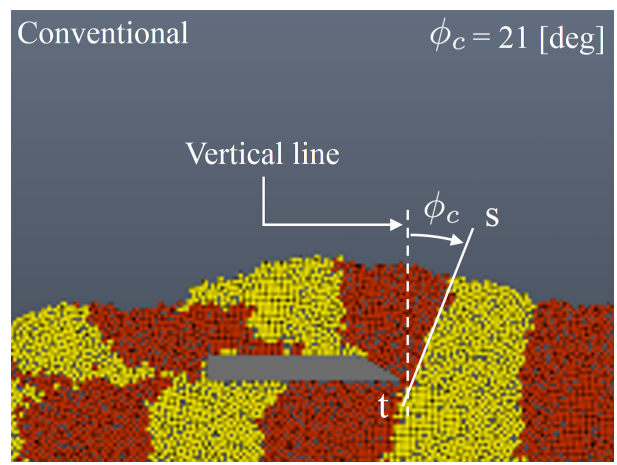

Fig. 21 Evaluation of the angle of the boundary line in the conventional path.

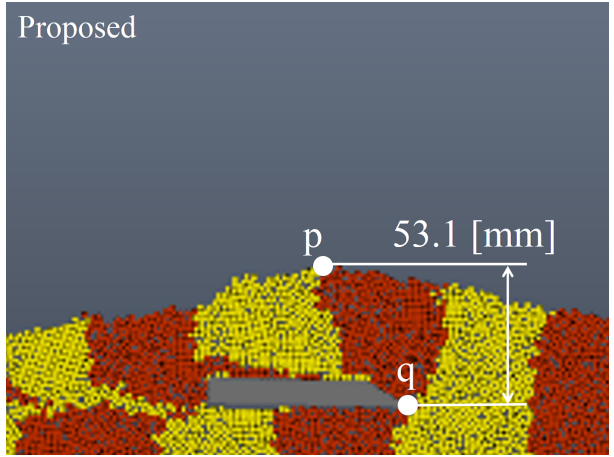

Fig. 20 A result of the simulation by the proposed path.

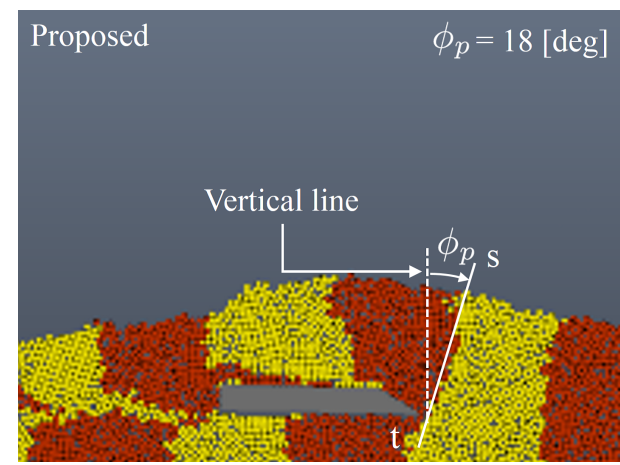

Fig. 22 Evaluation of the angle of the boundary line in the proposed path.

\section{DEM による検証結果}

\section{$7 \cdot 1$ 検証結果の概要}

6 章の検証条件と表 4 のパラメータに基づいて, 提案経路の効果をDEMによって検証した. 図 19 に従来経路 における解析の結果を, 図 20 に提案経路における解析の結果を示す. 以降では, 図 19 および図 20 の結果に基づ いて, 従来経路と提案経路の得失を比較する. 得失の比較には, 藤澤他（2015）による根切り刃先端における粒 子の層の傾き, 根切り刃上部における粒子の層の水平方向への圧縮率を用いる. なお, 図 19,20 において, 点 $\mathrm{p}$ は隆起の頂点を, 点 $\mathrm{q}$ は根切り刃先端を示しており, それぞれの図は, 根切り刃の一連の動作に伴い, 点 $\mathrm{p}$ と点 $\mathrm{q}$ の鉛直方向距離が最大となった状態を示している，それぞれ，従来経路では $49.4[\mathrm{~mm}]$, 提案経路では $53.1[\mathrm{~mm}]$ となった．なお，点 $\mathrm{p}$ と点 $\mathrm{q}$ の鉛直方向距離の大きさに着目する理由は，この值が根切り刃の潜りこみ及び土の隆 起量に起因するパラメータであることによる.すなわち, 藤澤他（2015）に示されているとおり, 点 $\mathrm{p}$ と点 $\mathrm{q} の$ 鉛直方向距離が大きいほど, 土の隆起量が大きくなり, 隆起した土が前方のホウレンソウに覆いかぶさるなどの 結果をもたらす可能性があることが多くの圃場実験において確認されている．ただし，隆起量とともに土の圧縮 や前方への移動量などが複合的に作用していると考えられるため, 点 $\mathrm{p}$ と点 $\mathrm{q}$ の鉛直方向距離に着目した状態で 粒子の層の傾きや圧縮の度合いによって, 設定経路の優劣を評価することとした。

\section{2 粒子の層の境界の傾きに基づく評価}

従来経路と比較するため, 藤澤他（2015）による粒子の層の境界に着目した評価に基づき，以下にその方法と 結果を示す. 解析結果である図 19 と図 20 において, 根切り刃の先端の点 $\mathrm{q}$ における土の層の傾きに着目する. そ のため, 図 19 と図 20 に対して新たに補助線 s-t を加えた図 21 と図 22 に基づいて評価する. 図 21 と図 22 の補助 線 s-t の鉛直軸からの傾きはそれぞれ $\phi_{c}=21[\mathrm{deg}], \phi_{p}=18[\mathrm{deg}]$ となり, 補助線 s-t の傾きは提案手法による結 果の方が約 $3[\mathrm{deg}]$ 小さくなった．土の層の傾きは土を前方に押し出している量の指標であるため, 可能な限り小 さいことが望ましい. よって, この観点において提案経路は従来経路に比ベホウレンソウの回収に有利であると 


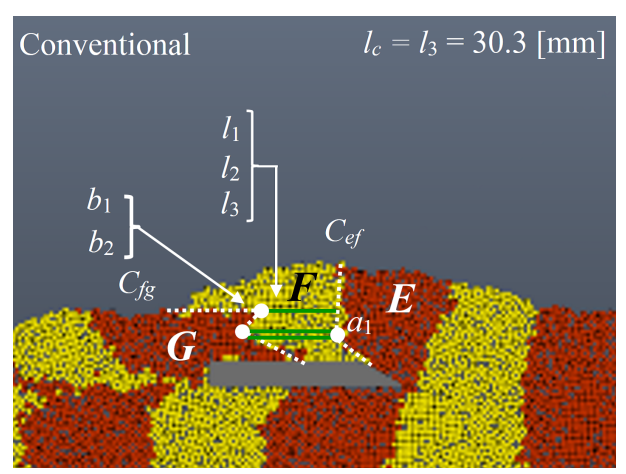

Fig. 23 Evaluation of the compression of particles in the conventional path.

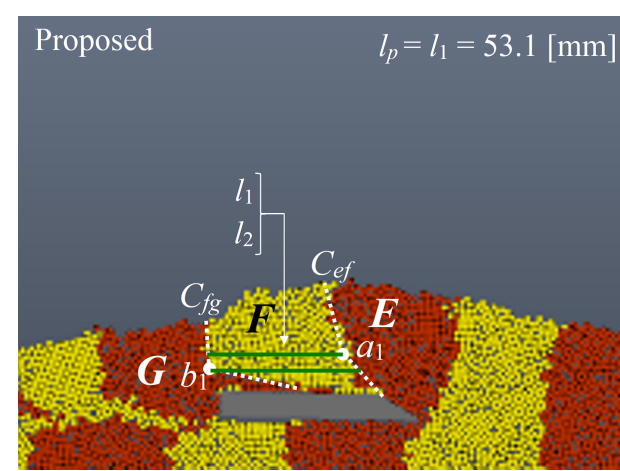

Fig. 24 Evaluation of the compression of particles in the proposed path.

いえる.

\section{$7 \cdot 3$ 粒子の圧縮に基づく評価}

検証結果を，粒子の水平方向への圧縮率の観点から評価する.まず，図 19 と図 20 に対して新たに補助線を加 える. 図 23 に従来経路に対する新たに補助線を加えた図を，図 24 に提案経路に対する新たに補助線を加えた図 を示す. 補助線は次のようにして引いている. 図 23 については, 根切り刃上部の土を根切り刃先端から後方に向 かって $E$ 層, $F$ 層, $G$ 層とし, $E$ 層と $F$ 層, $F$ 層と $G$ 層の境界をそれぞれ $C_{e f}, C_{f g}$ とする. ここで, $C_{e f}$ の折点 を $a_{1}, C_{f g}$ の折点を上から $b_{1}, b_{2}$ とする. このとき, $a_{1}$ から $C_{f g}$ へ, $b_{1}, b_{2}$ から $C_{e f}$ へ水平方向に補助線 $l_{1}$ から $l_{3}$ を引いている. 図 24 についても同様であり, $E$ 層と $F$ 層, $F$ 層と $G$ 層の境界線 $C_{e f}, C_{f g}$ のそれぞれの折点 $a_{1}$, $b_{1}$ から水平に補助線 $l_{1}, l_{2}$ を引いている. 図 23,24 の補助線のうち, 最小の長さのものをそれぞれ $l_{c}, l_{p}$ とする と, $l_{c}=l_{3}=30.3[\mathrm{~mm}], l_{p}=l_{1}=53.1[\mathrm{~mm}]$ となった. ここで, 初期状態における層の厚さ $50[\mathrm{~mm}]$ と圧縮後の 層の厚さの最小值 $l_{c}, l_{p}$ を用いて

$$
\beta_{c}=\frac{50-l_{c}}{50} \times 100[\%], \quad \beta_{p}=\frac{50-l_{p}}{50} \times 100[\%]
$$

を定義する．このとき $\beta_{c} ， \beta_{p}$ はそれぞれ最大の圧縮率を表す．図 23 に基づいて最大圧縮率を求めると $\beta_{c}=39.4$ [\%] となり, 図 24 に基づいて最大圧縮率を求めると $\beta_{p}=-0.06[\%]$ となった．藤澤他（2015）によれば，水平方 向における粒子の層の圧縮は根切り後のホウレンソウの根の箇所を硬くし回収を妨げる要因となるため, 可能な 限り小さいことが望ましい.よって, この観点においても提案経路は従来経路に比ベホウレンソウの回収に有利 であるといえる.

\section{8. 結 論}

本論文では, 土中を移動する根切り刃の適切な経路設計について議論した．従来の経路を基本としつつ, アー 厶長を可変とすることで根切り刃を常に根切り刃進行方向に拘束運動させるための機構動作の拘束条件を導出し, 拘束条件を利用した根切り刃経路を提案した. また, 従来経路に比較して有利となるアームの初期長さの条件を 導出した. さらに, 提案経路は従来経路よりも土を移動させにくいことをDEMに基づく解析によって検証した.

謝辞

本研究の一部は, 日本学術振興会科学研究費補助金, 基盤研究（A）, JP16H02352, の支援を受けて実施した.

文献

千田有一, 受動的ハンドリングに基づくホウレンソウ自動収穫装置の開発, 精密工学会誌, Vol.81, No.9 (2015), pp.815-818.

藤澤彰宏, 千田有一, 飯塚浩二郎, ホウレンソウ自動収穫機における土中での根切り刃運動による土の挙動解析, 日 本機械学会論文集, Vol.81, No.832 (2015), DOI:10.1299/transjsme.15-00298. 
畠山貴充, 藤澤彰宏, 山口達也, 千田有一, 小澤卓夫, 軟弱野菜自動収穫機における根切り刃の角度追従制御, SICE 中 部支部シンポジウム 2015, pp.5-8 (CD-ROM).

畠山貴充, 平野幸助, 中村雄太, 藤澤彰宏, 土屋貴司, 山口達也, 千田有一, 軟弱野菜自動収穫装置における土中での根 切り刃の位置制御, 第 3 回計測自動制御学会制御部門マルチシンポジウム (2016), PS-26 (CD-ROM).

ひらかさねっと, available from <http://www.hirakasa.net $>$ (参照日 2015 年 3 月 6 日).

平野幸助, 中村雄太, 土屋貴司, 千田有一, 嶌田武司, 藤ヶ崎静男, 北沢進, 軟弱野菜自動収穫機における根切り刃の 2

自由度制御機構の設計と制御, 第 56 回自動制御連合講演会（2013）, pp.1038-1042.

Jaroslaw, K. and Jan, S., Automation excavation process analysis for given trajectory and soil parameters, The 25th

International Symposium on Automation and Robotics in Construction (2008), PP.95-99.

小林由喜也, 簡易型ホウレンソウ収穫機の開発（第 1 報）, 農業機械学会誌, Vol.60 (1998), No.2, pp.103-110.

Lui, T., Wei, C., Liang, L., Zhang, J. and Zhao, Y., Simulation and analysis of the lunar regolith sampling process based on the discrete element method, Transaction of the Japan Society for Aeronautical and Space Sciences, Vol. 57, No. 6 (2014), pp.309-316.

中嶋洋, 離散要素法による土と車輪の相互作用の解析, 農業機械学会誌, Vol.68, No.2 (2006), pp.9-12.

長野県, 農業経営指標, available from <http://www.pref.nagano.lg.jp/nogi/keiei/keiei-top.html >(参照日 2014 年 6 月 27 日).

西澤准一, ホウレンソウなど軟弱野菜の加工向け専用収穫機の開発と普及への取り組み, 農林水産技術研究ジャー ナル, Vol.35, No.11 (2012), pp.37-41.

皿田滋, 大隅久, 松嶋厳, 桐生大輔, 掘削反力に基づくホイールローダのバケット軌道制御, 第 8 回建設ロボットシン ポジウム論文集 (2000), pp.229-234.

田中宏明, 個別要素法を用いた振動式全層破砕機の土層破砕メカニズム解明に関する研究, 京都大学博士論文 (2006). 山口達也, 千田有一, 藤澤彰宏, 軟弱野菜自動収穫装置における幾何学モデルを用いた根切り刃の経路設定と実機検 証, 第 3 回計測自動制御学会制御部門マルチシンポジウム (2016), PS-24 (CD-ROM).

吉田智一, 窪田潤, 前岡邦彦, ホウレンソウ収穫技術の開発（第 1 報）, 農業機械学会誌, Vol.62, No.3 (2000), pp.149156.

吉田達哉, 小泉孝之, 辻内伸好, 陳㑆, 中本洋造, 油圧ショベルの掘削作業における効率向上の検討, 日本機械学会論 文集 C 編, Vol.78, No.789 (2012a), pp.292-302.

吉田達哉, 小泉孝之, 辻内伸好, 陳㑆, 中本洋造, 逆動力学および個別要素法によるシミュレーションを用いた油圧 ショベルの掘削軌道の生成, Dynamics and Design Conference 2012, No.12-12 (2012b) (CD-ROM).

張海, 佐藤一彦, 板倉賢一, バケットマニピュレーションの軌道生成と制御 -ホイールローダの知能化に関する研究 （第 2 報）-, 資源と素材, Vol.117 (2001), pp.947-954.

\section{References}

Chida, Y., Development of an automatic harvester of spinach based on passive handling, Journal of the Japan Society for Precision Engineering, Vol.81, No.9 (2015), pp.815-818 (in Japanese).

Fujisawa, A., Chida, Y. and Iizuka, K., Behavior analysis of soil by motion of a root-cutting blade in soil for an automatic spinach harvester, Transaction of the JSME (in Japanese), Vol. 81, No.832 (2015), DOI:10.1299/transjsme.15-00298.

Hatakeyama, T., Fujisawa, A., Yamaguchi, T., Chida, Y., Ozawa, T., Angle tracking control of the root cutting blade of an automatic spinach harvester, Proceedings of Symposium of SICE Chubu branch (2015), pp.5-8 (CD-ROM) (in Japanese).

Hatakeyama, T., Hirano, K., Nakamura, Y., Fujisawa, A., Tsuchiya, T., Yamaguchi, T., Chida, Y., Control of the root cutting blade in the soil of an automatic spinach harvester, The 3rd Multi-symposium on Control Systems (2016), PS-26 (CD-ROM) (in Japanese).

Hirakasa-net, available from <http://www.hirakasa.net> (in Japanese) (accessed on 6 March, 2015).

Hirano, K., Yuta, N., Tsuchiya, T., Chida, Y., Shimada, T., Fujigasaki, S. and Kitazawa, S., Design and control of twodegree-of-freedom position control mechanism of a root cutting blade in a spinach harvester, the 56th Japan Joint Automatic Control Conference (2013), pp.1038-1042 (in Japanese). 
Jaroslaw, K. and Jan, S., Automation excavation process analysis for given trajectory and soil parameters, The 25th International Symposium on Automation and Robotics in Construction (2008), PP.95-99.

Kobayashi, Y., Development of simplified spinach harvester (part 1), trial manufacture of portable harvester and problems to improve, Journal of the Japanese Society of Agricultural Machinery, Vol.60, No.2 (1998), pp.103-110 (in Japanese).

Lui, T., Wei, C., Liang, L., Zhang, J. and Zhao, Y., Simulation and analysis of the lunar regolith sampling process based on the discrete element method, Transaction of the Japan Society for Aeronautical and Space Sciences, Vol. 57, No. 6 (2014), pp.309-316.

Nakashima, Y., An analysis of soil-wheel interaction by the discrete element method, Journal of the Japanese Society of Agricultural Machinery, Vol.68, No.4 (2006), pp.9-12 (in Japanese).

Nagano-ken, nougyou keiei sihyou, available from <http://www.pref.nagano.lg.jp/nogi/keiei/keiei-top.html> (in Japanese) (accessed on 27 June, 2014).

Nishizawa, J., Development and utilization of harvesting machine for spinach and other tender greens for processing use, Journal of Food and Agriculture, Vol.35, No.11 (2012), pp.37-41 (in Japanese).

Sarata, S., Osumi, H., Matsushita, G. and Kiryu, D., Motion control for bucket of wheel loader based on reaction force, the 8th symposium on construction robotics in Japan (2000), pp.229-234 (in Japanese).

Tanaka, H., Study on the solution of soil loosening mechanism by a vibrating wide subsoiler by means of the distinct element method, Doctoral Thesis at Kyoto University (2006) (in Japanese).

Yamaguchi, T., Chida, Y. and Fujisawa, A., Path planning of root-cutting blade by a geometric model of an automatic spinach harvester and experiment verification, The 3rd Multi-symposium on Control Systems (2016), PS-24 (CDROM) (in Japanese).

Yoshida, T., Kubota, J. and Maeoka, K., Development of harvesting technology for spinach (part 1) : development of prototype harvester and its performance, JOURNAL of the JAPANESE SOCIETY of AGRICULTURAL MACHINERY, Vol.62, No.3 (2000), pp.149-156 (in Japanese).

Yoshida, T., Koizumi, T., Tsujiuchi, N., Chen, K. and Nakamoto, Y., Examination of effective improvement in digging operation for hydraulic excavators, Transaction of the Japan Society of Mechanical Engineers, Series C, Vol.78, No.789 (2012a), pp. 292-302 (in Japanese).

Yoshida, T., Koizumi, T., Tsujiuchi, N., Chen, K. and Nakamoto, Y., Trajectory generation for digging operation with hydraulic excavator using simulation based on inverse dynamics and distinct element method, Dynamics and Design Conference 2012, No.12-12 (2012b) (CD-ROM) (in Japanese).

Zhang, H., Sato, K. and Itakura, K., Trajectory generation and control for scooping -Study on implementing machine intelligence into wheel loader (2nd report)-, Shigen-to-sozai, Vol.117 (2001), pp.947-954. 